\author{
Elena Davydenko \\ Saint-Petersburg State University \\ Department of Business Economics \\ Faculty of Economics \\ Elenadavidenko1@yandex.ru
}

\title{
Charitable activities of Russian companies
}

Date of submission: 16th of June 2017; date of acceptance: 25th of August 2017

JEL Classification: M14, L26, L31

Keywords: charitable organization, charity, activity, state, benefit, population

\section{Abstract \\ Charitable activities of Russian companies}

The article analyzes the activities of charitable organizations in Russia. The author explores the motives for carrying out charitable activities. Based on the results of the in-depth interview, the priority areas for the activities of charitable organizations in Russia, the requirements that the state should establish in relation to charitable organizations, as well as the specifics of interaction between the state and charitable organizations, are determined. The article also explores the fundamentals of legislative regulation of charitable activities in Russia.

\section{Introduction}

In recent years, an increasing number of Russian companies have been seriously considering issues of charity. Back in the 90s of the 20th century, when the country was just beginning the transition to democracy, and this transition took place spontaneously in Russia in comparison with European countries, charity issues for Russian business remained behind the scenes. And wherever they were, the companies sought to survive in the rapidly changing environment surrounding the external economic environment, hurriedly rebuilding their business while trying to apply Western business models. The main thing was to take care of yourself, not about others. However, "standing on their feet", the companies began to 
understand that care is needed not only for themselves. The aim of this article is to investigate the interaction of the state and charitable organizations in Russia and to identify problems that hinder the development of charity in Russia. The problem under discussion is a set of reasons hindering the development of charitable activities in Russia. The object of the research are charitable activities while the subject of the research is interaction between the Russian state and charitable organizations. The main thesis of the article is: the development of charity in Russia directly depends on the actions of the state in this area.

\section{Theoretical framework of the research}

Modern researchers, referring to the state of scientific development of the problem of Russian charity, call a various number - from 4 thousand to 11 thousand - of works, articles, authors and statistical collections that existed by 1917 and belonged to the pen of historians, archivists, clergymen, officials, state and public figures, publishers, etc. By the turn of the $19^{\text {th }}-20^{\text {th }}$ centuries, there had been already known a number of researchers who had chosen the history of the formation and development of charity in Russia, both in general and in separate directions, as a special subject for their research (Bensin V.V., Papkov A., Runkevich S.G, Yushkov S.V, Sokolovsky M.K, Kudryavtsev A.N, Maksimov E.D). Moreover, this research activity was encouraged in every possible way by the reigning house in the form of ranks, orders and prizes.

The importance of comprehending the history and experience of charity in the country was also evoked by the appearance of specialized journals in which were published materials covering the problems of the history, theory and practice of charity in the country and abroad: «Child Support», «Bulletin of Charity», «Labor Care» and «Charity in Russia».

The phenomenon of Russian charity was not studied at all during the Soviet period, because it contradicted the ideological principles of Russian historiography. Explanatory dictionaries and encyclopedias, if they mentioned such phenomenon as charity and philanthropy, gave them an assessment from purely class positions. Thus, the dictionary of foreign words treats philanthropy as "one of the means of the bourgeoisie to mask its parasitism and its exploitative face by means of hypocritical, humiliating" help to the poor "in order to divert them from the class struggle." We cannot say the same about foreign historiography. Almost all scientific literature, with a few exceptions, in the 80s and early 90 s of the $20^{\text {th }}$ century belongs to American researchers. Foreign scholars became the first in developing the basic methods of researching the history of charity as an integral part of social history. In particular researchers such as Bernik K. Madison («Social Security in the Soviet Union»), David L. Ransel (2009) (a study of socio-political opportunities for the emergence of educational homes in the period 
of "enlightened absolutism"), Joseph Bradley (article "Moscow Workhouse and the City Charity Reform in Russia"), who quite successfully identified and developed a number of particular aspects of the history of Russian charity.

Significant contribution to the study of the Russian social and charitable movement is made by A. Lindenmeyer (1992). In a series of articles, the author (Lindenmeyer 1992), basing on extensive theoretical and factual material, has thoroughly worked out such subjects as the charitable activities of urban guardianship of the poor, the participation of Russian women in the charitable movement, and the epic of charity in tsarist Russia.

Already in our times, since the mid-1980s, after several decades of oblivion, interest in the history of charity (first of all, as indisputably the positive factor of the national modernization process) revived again. In particular, it is a monograph by Vlasov P.V. "The Abode of Mercy", where an attempt is made to revive undeservedly forgotten names and to talk again about the prestige of the traditions of charity (Vlasov 1991). The scientific research of Nuvakhov B.S. (1993) considers charitable organizations in the field of medicine. Monograph of Ulyanova G.N. (Ulyanova 1999) considers the charity of Moscow Entrepreneurs 1860s-1914. The work of the historian P.V. Vlasov describes the history of the creation and activities of Moscow charitable institutions, the book of A.N. Bohanov (1989) "Collectioners and patrons in Russia" dedicates to the representatives of the industrial and commercial dynasties, the most famous patrons and collectors.

In the spring of 2009, CAF Russia conducted the study «Charity in the Conditions of Economic Crisis». CAF Russia prepared recommendations for companies interested in preserving and developing their charitable activities in terms of an economic crisis. The recommendations contained a number of practical tips on the possible ways of transforming corporate charitable activities, the forms of effective charitable programs, represented the outlines of mutual relations, mutually beneficial for companies and non-profit organizations. The main recommendations given by CAF Russia to companies were as follows:

1. Engage employees more actively in charity activities of the company. It is about both building and expanding the programs of corporate volunteering, as well as the development of cash donations to the company's employees.

2. Use the potential of the pro bono mechanism. This kind of charity is to provide professional assistance to the non-profit organizations, for example, financial, legal, accounting, and marketing services.

3. Use the "non-monetary" opportunities of the company. Assistance with things, provision of premises, choice of non-profit organizations as a provider of services or products, and so on.

4. Increase the effectiveness of charitable activities. Increasing companies' attention to the social effect of corporate charitable programs is an important vector of the transformation of corporate charitable activities in terms of crisis. 
5. Develop a partnership approach to charity. According to the research, the expansion of the partnership approach through cooperation with other companies and non-profit organizations is in the focus of attention of companies that are thinking about optimizing their charitable activities.

6. Cooperate with professional partners from among non-profit organizations. As partners for the implementation of charitable activities, it is necessary to choose non-profit organizations that can contribute not only to the philanthropic mission of the charity programs of the company, but also to solve the problems that the business faces.

7. Correct the subject of charitable activities, taking into account the expectations of society and the state. According to the research, both companies and non-profit organizations forecast an increase in the request for consultations on the protection of rights and interests (primarily social and economic rights), vocational training, employment, development of small businesses. When planning charitable activities, companies should take into account the needs of society, which can be learned from research or a specially organized dialogue with stakeholders.

8. Support the infrastructure of the charitable sector. Do not be afraid to invest in the institutions of support for the charitable sector - improving attitudes toward charity will help companies to gain support from the community. It is about supporting activities aimed at popularizing charity in general, and corporate philanthropy in particular; joint actions of the sector's participants in spreading the best practices of corporate philanthropy, creation of conditions for the development of private donations, lobbying for relaxation of the tax regime for corporate donors, and so on.

In this article, we will try to understand the current state of relations between the state and companies that carry out charity in Russia and propose ways for their further interaction.

\section{Research methodology}

In the study, we applied tools such as comparative analysis, structural analysis. The main method of research was an in-depth interview aimed at revealing the attitude of Russians to charitable activities in Russia. For the purposes of the study, we interviewed 200 Russians of different ages using an online survey. The respondents were asked to answer the following questions of the questionnaire:

1. In what way could you evaluate relations between the state and Russian charitable organizations?

2. Do you consider the position of the state in relation to charitable organizations in Russia correct?

3. Do you consider the state is entitled to present certain requirements to Russian charities? 
4. Which requirements should the state entitle to Russian charitable organizations?

5. Should the authorities monitor the true motives for doing business in charitable organizations?

6. Should the state control the activities of charitable organizations in Russia?

7. In which branches of the social sphere, charitable activity is especially necessary and in what sectors should it receive the maximum state support in the coming years?

Respondents were not offered options for answering questions. The answers received from the respondents during the processing of the results of the in-depth interview were grouped. The results of the study are presented in this paper.

\section{Analysis of research results}

When the first McDonald's opened in Russia in the early 90s, this company was already actively involved in the protection of children - in any restaurant of this network there is a box for donations to the Ronald McDonald House. The character, the clown Ronald McDonald, was coined and started to be used by the company in the 60 s of the 20th century as a character that attracted children's attention and participated in McDonald's commercials. MacDonald's began to engage in philanthropy in 1984, assisting children with disabilities. The company created a charitable international fund called "Ronald McDonald's House", whose activities are currently extended to forty-eight countries. In Russia, this fund began its activity in 1995. Over the years of work, this fund has collected more than 420 million dollars, which were aimed at providing social, psychological and medical assistance to sick children. In Russia, the Ronald McDonald Foundation helps the children's homes and sick children. It is remarkable that the company McDonald's really made efforts to ensure that Ronald became a symbol of good in different parts of the world. So, in Thailand, Ronald welcomes children in Thai traditions, pressing both hands to each other. The Thai image of Ronald was created in 2002, and then spread to India, as well as those countries where this gesture is used as a greeting. In Japan, where McDonald's is one of the most popular fast food chains, Ronald is called Donald because of the absence of the Japanese letter "p" (Frolova 2014).

However, there is a reasonable question - do companies carry out charitable activities only of altruistic motives? As the director of the CAF (Charities Aid Foundation) Russia Maria Chertok notes, "companies are engaged in charity primarily because it is important for them to manage their reputation in the communities in which they work." Similar terms to charity are the terms "donation" and "patronage". Charity and donations cannot be delimited; both of these concepts are parts of one whole. At the same time, a donation is a way to transfer financial resources on a gratuitous basis for the implementation of a certain project. Charity 
does not necessarily imply the existence of a specific funded project, but can be carried out on a continuous basis. Patronage is a narrower concept, mainly associated with supporting projects in the field of culture and art (Chertok 2017). The CAF Foundation (Fund for the Support and Development of Philanthropy of KAF) has existed in Russia since 1993 and operates as a representative office of Charities Aid Foundation (CAF), one of the oldest charitable foundations in Britain. The Russian office of the fund is the most numerous international office of CAF. Annually the Foundation implements more than 20 charitable programs in close cooperation with leading Russian and international companies. So, since 2012 the fund has been actively cooperating with Coca-Cola. In preparation for the Winter Olympic Games in 2014 in Sochi, with the support of the foundation, a program was implemented to develop skills for healthy lifestyle among schoolchildren in Sochi. Then a joint project was launched to increase the accessibility of mass sports. Nineteen sites were built as part of the project to increase the accessibility of mass sports, including for people with disabilities, in twelve Russian cities: Yekaterinburg, Barnaul, Volgograd, St. Petersburg, Ulyanovsk, Sochi, Moscow, Tver, Nizhny Novgorod, Rostov On Don, Kazan, Samara. To build sports grounds and conduct activities to involve people in sports, in the framework of a joint program with Coca-Cola, about 20 million rubles were spent.

According to the World Giving Index-2015 published by CAF Russia takes 9 place by the number of people volunteering time.

Table 1. Number of people involved in charitable activities

\begin{tabular}{l|c|c}
\hline & Place & People $(\mathrm{mln})$ \\
\hline India & 1 & 157 \\
\hline United States of America & 2 & 115 \\
\hline Indonesia & 3 & 68 \\
\hline China & 4 & 47 \\
\hline Nigeria & 5 & 32 \\
\hline Japan & 6 & 29 \\
\hline Philippines & 7 & 28 \\
\hline Russia & 8 & 23 \\
\hline Germany & 9 & 23 \\
\hline Brazil & 10 & 21 \\
\hline
\end{tabular}

Source: CAF Report (Nov, 2015).

The total place of Russia in the CAF ranking from the year 2015 is 129. In the previous years the place was lower than 120 . The dynamics of Russia's indicators is included in the overall trend: in general, according to the report, more people in the world become volunteers and do good matters, helping strangers, but donations to non-profit organizations do not grow. 
We conducted research on the evaluation of the attitude of Russians to Russian charitable organizations and relationship between the state and Russian charitable organizations. For the purposes of the study, we interviewed 200 Russians of different age using an online survey. The respondents were asked to answer the questions of the questionnaire. According to the results of the survey, we received answers that allow us to assess the attitude of Russians towards charity. Therefore, $27 \%$ of respondents considered that the state encourages charities development, $17 \%$ that it establishes cooperation with them as equal partners. Almost every sixth $(18 \%)$ agrees that the state is trying to help and cooperate with Russian charitable organizations, but does it clumsily. According to $11 \%$ of respondents, the state ignores such organizations or treats them indifferently. According to $9 \%$ of respondents, the state is trying to establish control over such organizations. Only $3 \%$ of the population adhere to a very extreme point of view, believing that the state is trying to destroy Russian charitable organizations. $9 \%$ of respondents noted a lack of consistent state policy in this area, and 6\% believe that there is a big gap between the state's proclaimed and actual policy towards Russian charitable organizations.

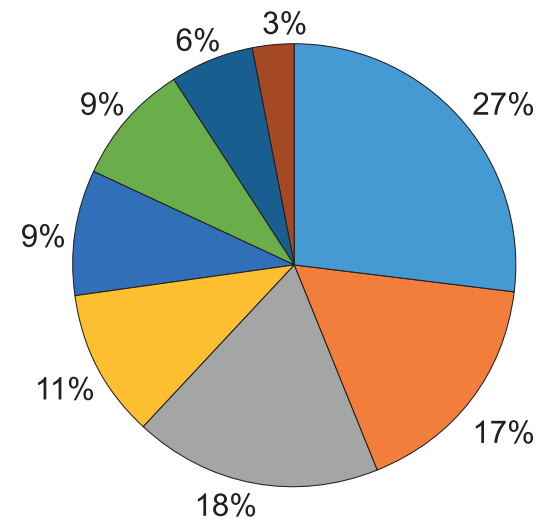

The state encourages development of charitable organizations

The state establishes cooperation with charitable organizations as equal partners The state is trying to help and cooperate with Russian charitable organizations, but does it dumsily

$\square$ The state ignores charitable organizations or treats them indifferently

The state is trying to establish control over charitable organizations

$\square$ There is a lack of consistent state policy in this area

There is a big gap between the state's proclaimed and actual policy towards Russian charitable organizations

The state is trying to destroy Russian charitable organizations

Figure 1. The results of in-depth interview (2017). The question: in what way could you evaluate relations between the state and Russian charitable organizations?

Source: conducted by the author of this article. 
The validity of this distribution of opinions is confirmed by the respondents' assessments of the correctness/incorrectness of the position of the state in relation to Russian charitable organizations. $42 \%$ of respondents considered this position correct, 20 - incorrect, and $38 \%$ of respondents found it difficult to determine their opinion.

According to $44 \%$ of the population, the state should create favorable conditions for the activities of all charitable organizations, without exception. The same number of supporters have the opinion that this should be done only for such organizations that really help people, bring them benefits. Much less respondents $(17 \%)$ indicated that the state should help the charitable organizations whose activities do not harm the society and the country. For $16 \%$ of the population, the criterion in this matter is the participation of the organization in solving problems of local life in the city or village. $10 \%$ of the population noted that it is necessary to create favorable conditions for those organizations that participate in solving tasks set by the country's leadership and those that donate large amounts of money.

The survey participants were also asked to comment on whether the state is entitled to present certain requirements to Russian charities in exchange for their support, creating favorable conditions for their development. The overwhelming number of respondents are agree with this thesis. Only 5\% of the respondents oppose such a statement of the issue — no demands are required, and $8 \%$ found it difficult to determine specific requirements.

Every second respondent focused on the requirement to strictly enforce the laws. Almost as often $(42 \%)$ respondents noted the requirement not to participate in corruption, tax evasion, covering unscrupulous business. More rarely, the requirements were to provide detailed and reliable reporting (34\%), conduct high-performance activities (20\%), coordinate the goals and objectives of the organization's activities with government bodies $(18 \%)$ and be proactive $(12 \%)$. Less than $10 \%$ of respondents supported the following requirements: to follow ethical standards more stringently than in commercial organizations; not participate in political activities; to show loyalty to the authorities, to support its initiatives; to refuse support from abroad; to abandon close contacts with business; limit its commercial (revenue-generating) activities. The results are presented in Figure 2.

It is characteristic that, according to the research, $72 \%$ of Russians agree that the authorities should monitor the true motives for doing business in charitable organizations. Only $16 \%$ have the opposite opinion. Slightly less were those who found it difficult to answer this question.

Thus, most Russians agree that the state should somehow control domestic charitable organizations. Speaking about the definition of objects and priorities of charitable activities, the population is inclined to give their choice to Russian charitable organizations. As for the role of the state in this process, the majority of the respondents (48\%) spoke in favor of informing about state priority goals and tasks and creating conditions for the voluntary participation of charitable organiz- 
ations in their implementation. $28 \%$ of respondents, on the contrary, felt that the state should not influence the choice of priorities of organizations. Almost one in five $(19 \%)$ chose to prioritize and encourage charitable organizations to implement them. Every tenth respondent found it difficult to answer this question.

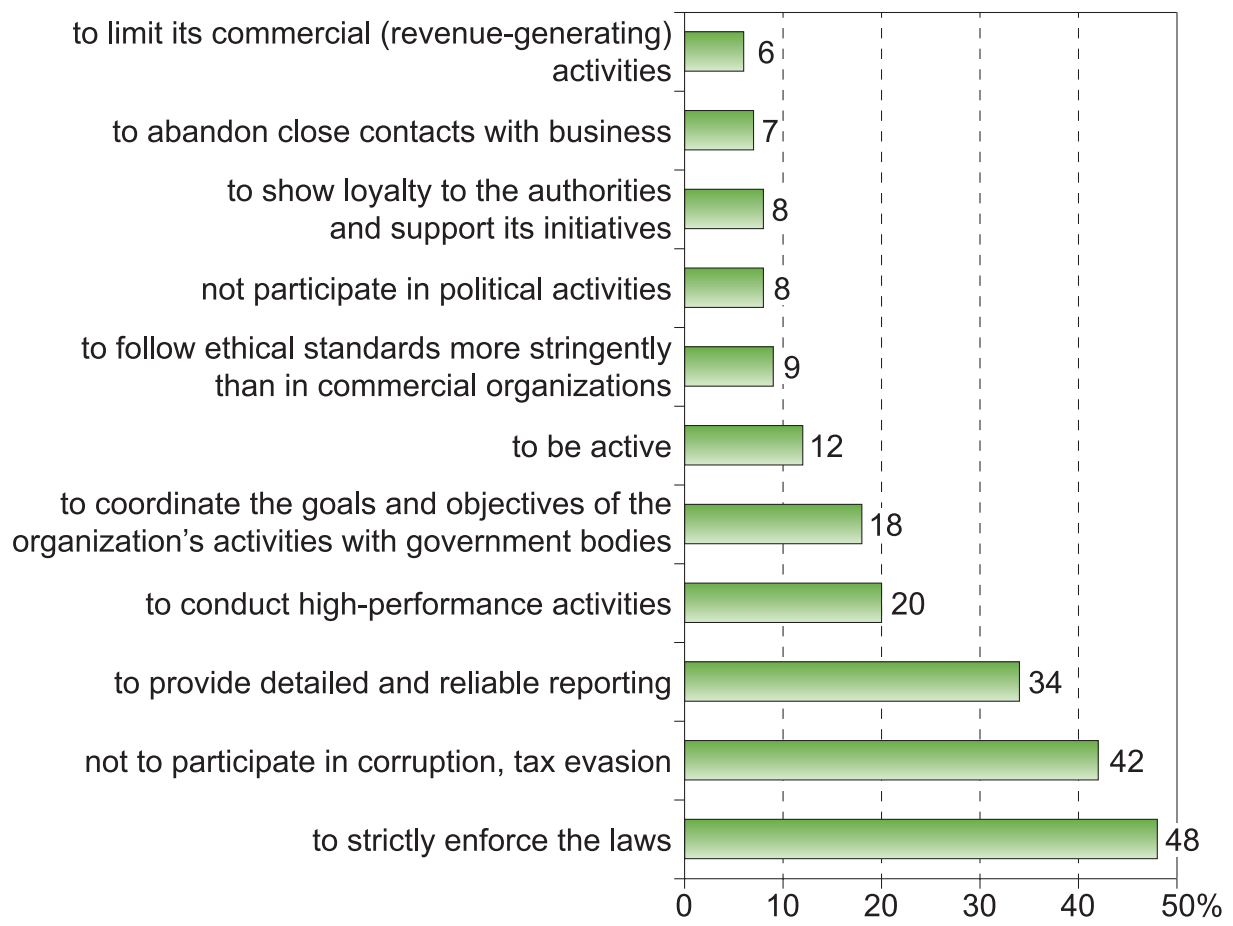

Figure 2. The results of in-depth interview (2017). The question: which requirements should the state entitle to Russian charitable organizations?

Source: conducted by the author of this article.

To put on a systematic basis the interaction between the state and Russian charitable organizations is possible through a program-targeted approach, and the Concept for the Promotion of Charity and Volunteerism, developed by the Ministry of Economic Development of Russia, can play a key role in this matter. Distribution of respondents' answers to the question "In which branches of the social sphere charitable activity is very important?" Thus, according to the majority of Russians, charity in Russia today is especially needed in the field of maternity protection, paternity and childhood (66\% of respondents indicated this). On the second place in the rating of respondents on the need for assistance are the socially vulnerable segments of the population (18\% of respondents). The need for education and medicine in charity was noted by $11 \%$ of the survey participants. The rest of the social sphere, according to the population, does not need charitable activities so much, and state support should be provided, but not in the first place. 


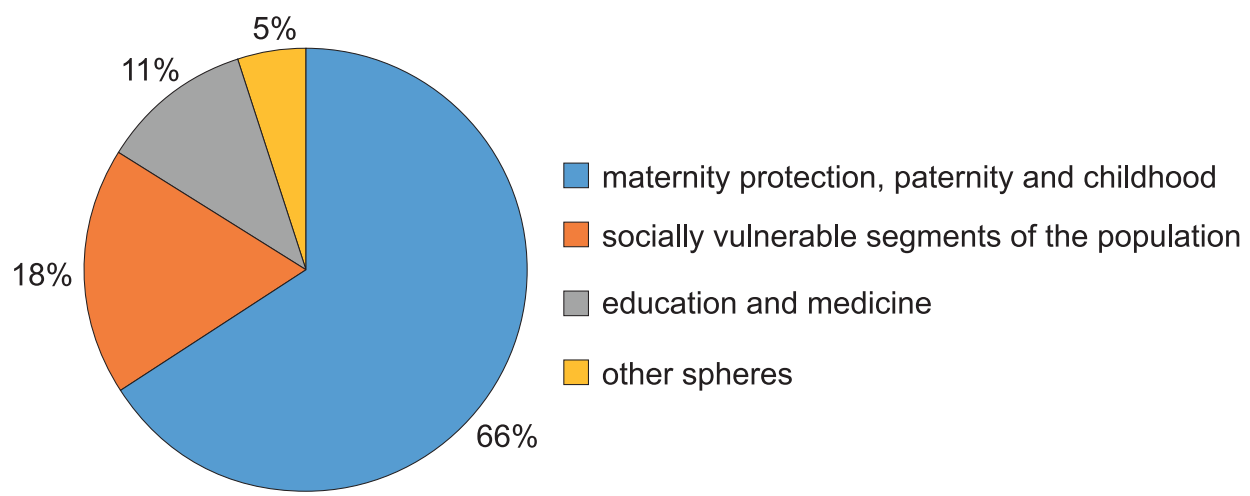

Figure 3. The results of in-depth interview (2017). The question: what areas are priority for Russian charitable organizations?

Source: conducted by the author of this article.

A logical question arises: how is charitable activity governed by Russian legislation? The Federal Law of 11.08.95 No. 135-FZ «On Charitable Activities and Charitable Organizations» regulates charitable activities in Russia (hereinafter - Law No. 135-FZ). According to the law above, charitable activity is understood as the voluntary activity of citizens and legal entities for the disinterested (free or concessional) transfer of property (charitable donations) to citizens and legal entities (non-profit organizations), including monetary funds, to the unselfish performance of work, the provision of services, providing other support. Participants in charity are philanthropists, volunteers and beneficiaries (Article 5 of Law No. 135-FZ). Philanthropists are persons who carry out charitable donations. Philanthropists have the right to determine the purposes and order of using their donations. Volunteers are citizens who carry out charitable activities in the form of gratuitous labor in the interests of the beneficiary, and in the interests of the charitable organization. A charitable organization can pay the costs of volunteers related to their activities in this organization (travel expenses, transport costs, etc.). The beneficiaries are persons who receive charitable donations from benefactors, and volunteer assistance.

How is the activity of the benefactor taxed? It should be noted that in the case of gratuitous transfer of goods (performance of work, provision of services) within the charitable activities for the purposes specified in Law No. 135-FZ, there is no obligation to pay VAT. It should be remembered that if the organization carries out activities, both taxable and not taxable (VAT exempted from VAT), it is obliged to keep separate records of such transactions (clause 4 of Article 149 of the Tax Code of the Russian Federation). As for the profit tax, the value of the donated property and the costs associated with such transfer are not taken into account for profit tax purposes (clauses 16 and 34 of Article 270 of the Tax Code of the Russian Federation). At the same time, the Russian Ministry of Finance, in 
a letter dated 04.04.2007 No. 03-03-06/4/40, indicated that the expenses incurred by the organization in the framework of charitable activities could not reduce the tax base for income tax, since they do not meet the requirements of Art. 252 of the Tax Code. What happens to the taxes of a benefactor applying a simplified taxation system? A taxpayer who uses "simplified tax" cannot reduce the income received by the amount of charitable assistance. The list of expenses for which payers of simplified taxation system can reduce the profit received, is given in art. 346.16 of the Tax Code and is closed. The costs of charity in this list are not listed (Feoktistova 2010).

By what principle do companies choose objects for charitable activities? It can be noted that all companies have priority areas that are determined by the social policy of the company: someone cares about sports, someone focuses on the environment, and someone helps children. In the event that companies do not know where their donations could be useful, it is necessary to analyze the problems of the region in which the company operates and, accordingly, make a choice of the charitable object.

Thus, Kellogg Rus, a Russian subsidiary of the international company Kellogg, one of the leading producers of crackers, cookies, ready-to-eat breakfasts and industrial semi-finished products, is actively engaged in charitable activities. Twelve modern automated lines are located at four plants - in Voronezh, Pskov, Smolensk region and Krasnodar territory - and sales offices are located throughout Russia. On February 1, 2017, the company launched the "Buy Lubyatovo help to feed needy children in Russia" campaign. The purpose of the charitable action is to enable the company to produce additional products for charity. The partners of the company Kellogg Rus are the Rus Food Fund and the Charity Aid Service. The company Kellogg Rus plans to transfer the products of Lubyatovo to more than 50,000 needy children of Russia. In 2016, the company has already helped more than 160,000 needy children across Russia. It is worth noting that the charity campaigns are carried out by the brand "Lubyatovo" from 2013 onwards annually. In 2015, thanks to this kind action, 5,000,000 servings of breakfasts were produced and handed over to more than 33,000 Russian families in a difficult life situation (Lubyatovo 2016).

As for the famous Russian politicians? Do they pay attention to charitable activities? So, Sergey Kirienko, the first deputy Head of the Presidential Administration of the Russian Federation, confirmed that all monetary prize received after leaving Rosatom was paid to the fund for combating childhood cancer. By the way, back in 2015, during his press conference, President Vladimir Putin said that the first persons of state companies could send part of their personal income to charity - "they will not become impoverished". At the same time, representative of Rosneft Mikhail Leontiev said that the head of the company Igor Sechin "has already sent one of the additional sources of remuneration" to charity. It is also known that in 2017 the State Duma Speaker Vyacheslav Volodin transferred 
5 million rubles to Dr. Lisa's fund, and Sergei Ivanov, the President's special envoy for ecology and transport, 2 million rubles to support the Far Eastern leopards and museums of the Kremlin (Maximenko 2017).

At the same time, not all Russian companies understand the importance of charitable activities. The positive aspects of the current situation in this area include the readiness of a significant part of society to participate in charitable activities, as well as the rather developed social activities of charitable organizations. The disadvantages include insufficient amount of charity donations in comparison with Western countries, a gap between the expectations of citizens and the business community's notions of social responsibility, underdevelopment of social investments, distrust of society and business to charitable organizations and funds. Both private individuals and business circles are ready to help most often targeted and the most unprotected: children and the elderly people.

\section{Conclusions}

Making conclusions, it should be said that in order to increase the activity of the population in the sphere of charitable activities in the forms of donations and voluntary labor on a gratuitous basis, the state should:

- morally encourage and reward both representatives of charitable organizations, and private benefactors, donors; ities;

- provide benefits for donors and reduce / cancel taxes on charitable activ-

- form a positive image, draw attention to the activities of charitable organizations;

- to create favorable socio-economic conditions in the country, in particular to raise wages, improve the well-being of the population (increase incomes to have something to share);

- cooperate with charitable organizations, create favorable conditions for the development of these organizations, in particular to promote the improvement of infrastructure and financial stability.

\section{References}

Bohanov, A.N. (1989), Collectors and Patrons of Art in Russia, Moscow.

CAF World Giving Index 2015. Retrieved November 29, 2015, from https://www.cafonline.org/docs/ default-source/about-us-publications/caf_worldgivingindex2015_report.pdf.

Chertok, M. (2016), Director of the CAF Russia Foundation: "Charity is a reputation". Retrieved December 26, 2016, from www.coca-colarussia.ru.

David, L. Ransel (2009), A Russian Merchant's Tale. The Life and Adventures of Ivan Alekseevich Tolchenov: Based on His Diary, Bloomington-Indianapolis.

Federal, Law of 11.08.95 No. 135-FZ «On Charitable Activities and Charitable Organizations». 
Feoktistova, A. (2010), “Charity: Do I have to pay taxes?”, New Accounting, 5, pp. 10-17.

Frolova, L. (2014), Ronald McDonald is the mascot of the company McDonalds. Retrieved May 27, 2014, from http://fb.ru/article/141451/ronald-makdonald---talisman-kompanii-mcdonald-s.

Lindenmeyer, A. (1992), Voluntary Charitable Societies in the Era of the Great Reforms, in: Great Reforms in Russia (Collection), Moscow.

Lubyatovo launches charitable action to help children (2016). Retrieved March 17, 2016, from http://www.polit.ru.

Maximenko, A. (2017), "Volunteers do not respect us. Volunteer about 'fashion' for charity”, Weekly "Arguments and Facts", 8, pp. 10-12.

Nuvakhov, B.S. (1993), The history of charity and charity in Russian medicine XVIII - early XX centuries. Diss. for the degree of Doctor of History, Moscow.

Ulyanova, G.N. (1999), Charity of Moscow businessmen: 1860-1914, Moscow.

Vlasov, P. (1991), The Cloister of Mercy: On pre-revolutionary Moscow charitable institutions. Moscow: Prospect. 